\title{
クモ膜囊腫破裂によって生じた慢性硬膜下水腫例
}

\author{
慢性硬膜下血腫成立への・形態として \\ 楠野 幸次·吉田 康成·高橋愛一郎·石井 昌三*
}

\section{Chronic Subdural Hygroma Caused by Rupture of Arachnoid Cyst}

As a Probable Course to Chronic Subdural Hematoma - Case Report-

Koji Kusuno, Yasuaki Yoshida, Aiichiro TakahashI and Shozo Ishiı*

Section of Neurosurgery, Second Department of Surgery, St. Marianna University, Kawasaki, Kanagawa; * Department of Neurosurgery, Juntendo University, Tokyo

\begin{abstract}
The patient was a 25-year-old male, who sustained a head injury and was found to have an asymptomatic arachnoid cyst of the middle cranial fossa and a frontal subdural space. Complete communication between the subdural space and the subarachnoid space was recognized on CT performed 5 days after the injury, but not on CT 35 days after the injury. No hemorrhage was found in the subdural space on follow-up CT. Operation was performed 42 days after the injury. It was found that the subdural space contained xanthochromic fluid and that the capsule of the hygroma was very similar histologically to that of chronic subdural hematoma in adults. In this case, tear of the arachnoid membrane and accumulation of CSF in the subdural space were considered to have been essential for the formation of chronic subdural hygroma.

It was thought that adults with brain atrophy and infants with craniocerebral disproportion, like those with arachnoid cyst, tend to have their arachnoid membrane torn by minor head injury and that this tends to form chronic subdural hygroma. It was reported that chronic subdural hygroma might be transformed into chronic subdural hematoma. Tearing of the arachnoid membrane might be one important factor in the development of chronic subdural hematoma.
\end{abstract}

Key words: subdural hematoma, subdural hygroma, arachnoid cyst, metrizamide CT cisternography, cerebrospinal fluid

\section{Iはじめに}

中頭蓋葴クモ膜囊腫はCT 導入以来診断が容易上な $\eta^{11}$ ，付随的に見い出される無症状例を経験することがあ

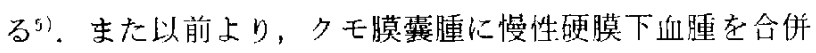
した報告例屯散見される多,11：我々は，中䫓荒䆚夕モ膜 囊腫が頭部打撲を契機として硬膜下腔に破れ，慢性硬膜下
水腫を形成した症例を経験した。経過観察々手術所見上り 慢性硬膜下血腫との関連を考祭したので報芒する.

\section{II 症例}

<忠者>25才，男性

主訴：頭部打撲

家族歴：特記すべきことなし

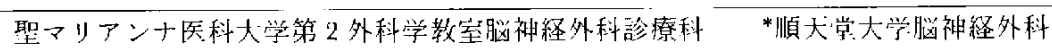

Address reprint requests to: K. Kusuno, M.D., Section of Neurosurgery, Second Department of Surgery, St. Marianna Unjversity, 2,095 Sugao, Miyamae-ku, Kawasaki, Kanagawa 213.

受稿

1983年 8 月18日受理 1984年1月23日 
既往歴：先天性眼振

現病歴：1983年3月9日，軽トラック連転中乗用串と正。 面衝突し，トラックは横転した。前額部を打撲し挫創在受 けたが，意識障害はなく，1時間㣪に当学救命救急センタ ーに入院しなった。

入院後経過：入院時，意識障害などの異常は誌められ ず，頭部挫㓣の縫合処㯰のみがなされた，頭部単純レント ゲン写真では骨折は認められなか一た，CT スキャンでは

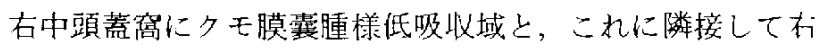
前頭骨直トに溥い低吸収域孛認めた（Fig.1A)。受傷媛 3
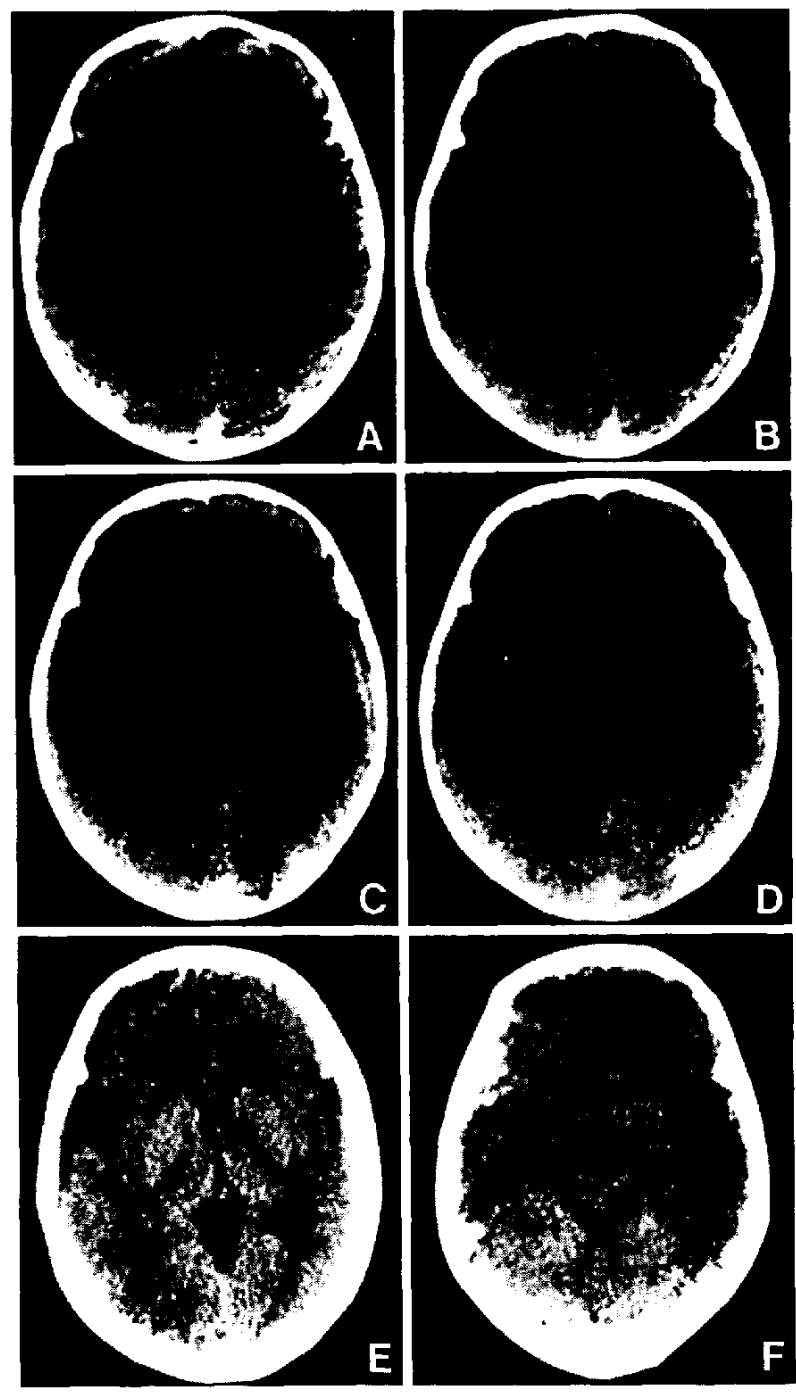

Fig. 1 Sequential CT scans show gradual enlargement of the right frontal subdural space. A: 'Two hours, B: 3 days, C: 8 days, D: 13 days, and E: 30 days after injury. This space is not seen on the postoperative CT. F: 14 days after operation.
日目のCTスキャンでは，この薄い低吸収域は增大豙示し た（Fig.1B）。受傷娞 5 月目の metrizamide CT cisternography では，造影剤注入後 2 时間でこれらの異常低吸 収域すべてに造影剤の分们を碓認し，24時間偻には造影剂 は完全に消失していた(Fig. 2)。受鹪後 8·13・30日目と GTスキャンにて追䟢すると，骨直下゙の低吸收域は前頝上 り側頭，頭頂へ上搪大し，右加左八の軽微な正中偏位を 呈するに至った(Fig. 1C〜 E)，しかし，臨床的には特別な 症状は出現しなかった。受傷後35日目の metrizamide CT cisternographyで注，造影剂拄入 $3 \cdot 6$ 時間後において CT 优測定でのみ判別できる程度の造影剂の異常低吸收域风一 の移行を諗め，24・48時間後には造影剂の遺残は認めなか った(Fig. 3)。なお，6時間徯のCT 像では夕モ膜囊腫様 低吸收域で島部に面する部分に正常クモ膜ト腔の明瞭な造 影を認めた，骨直下の異常低吸収域が徐々に抬大し慢性硬 膜下水腫の所見を呈してきたため，受傷後42日目の1983年 4月20日，右前頭側頭䣓頭術老施行した。

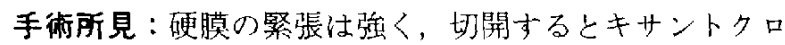
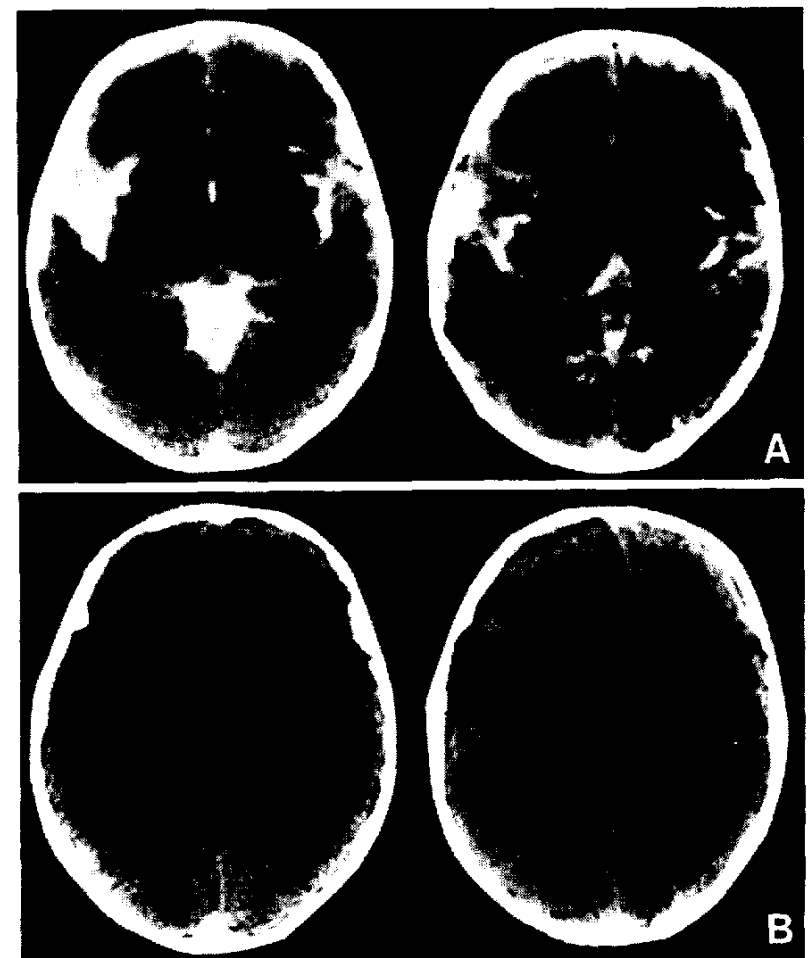

Fig. 2 Metrizamide CT cisternographs performed 5 days after injury, obtained 2 hours (A) and 24 hours after intrathecal administration of metrizamide $(B)$. Distribution of the contrast medium to the abnormal low-density area is recognized 2 hours after intrathecal administration. Metrizamide is completely washed out 24 hours after injection. 
ミ一様湾の噴出を認めた。液の性状は蛋白 $2,436 \mathrm{mg} / \mathrm{d} l$,

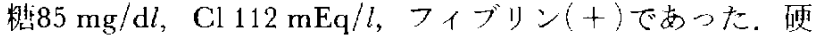
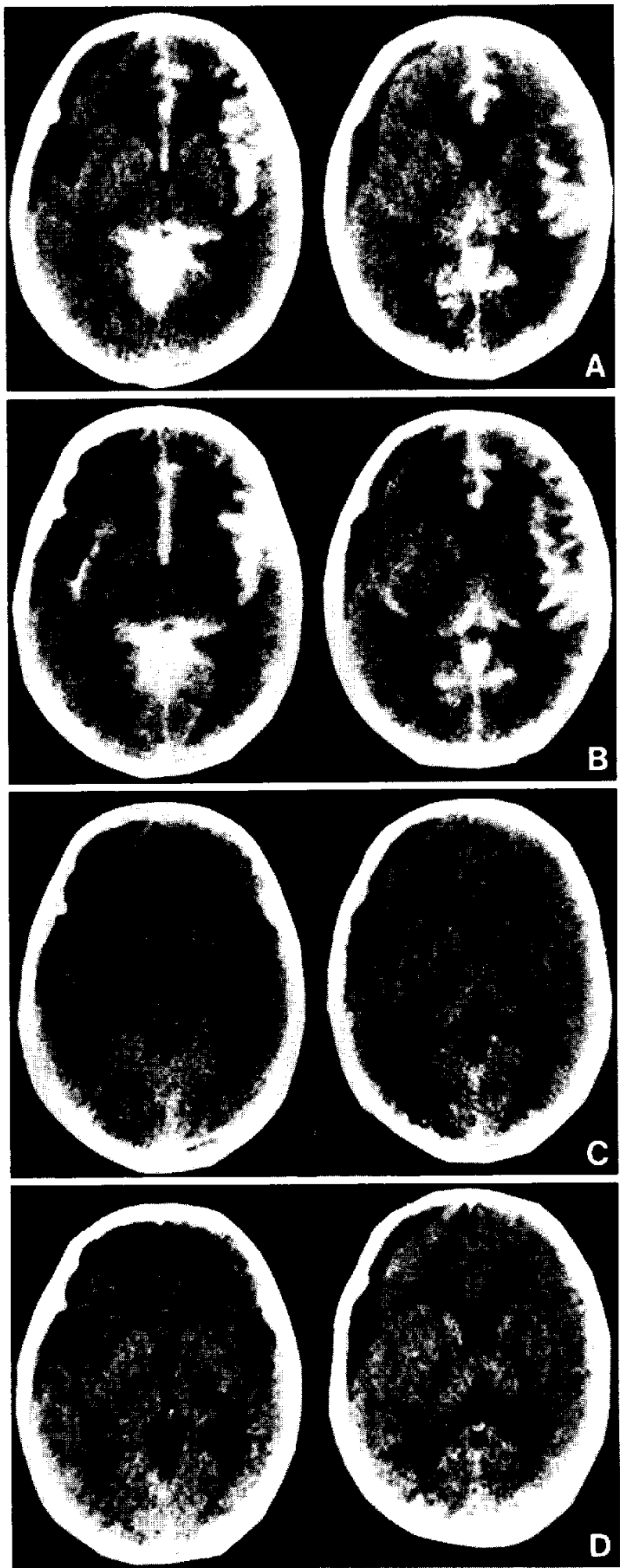

膜内面に接し兏↔で半透明の水腫外膜と思われる膜满造を 確認し，この一部を標本として採取した。水腫内膜は脳表 クモ膜」に、クモ膜の肥厚の上5に見元た。クモ膜囊腫は 中頭盖窝に媣く入り込んでいたが，上壁の一部で輪状に破 れて硬膜下水腫腔上大きく交通して㧍り，この破れた霊䛲 卜壁の一部を標本として採取した(Fig. 4)。硬膜下゙水腫脂 内では，ほとんど索状化した数本の静脈が硬膜と脳表の間

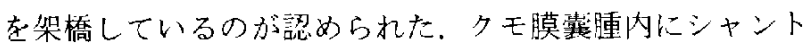
チューブを設置し, 腹胎內一と尊いた。

術後経過：術後 1 週間は低㭪道液圧による上出われる頭痛 老訴えたが，しだいに消失した。術後14日目のCTスキャ ンでは, クモ膜囊腫，慢性硬膜下水腫は消失していた (Fig. 1F).

\section{III 考察}

クモ膜翼腫は1831年の Bright の報告以米，数多く報告

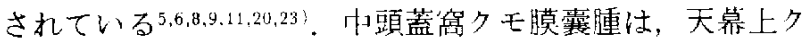
モ膜囊腫の䄪半数を占めると言われる は，Starkman ら21 の言う系統発生過程におけるクモ膜の 異常によって牛ずる(intraarachnoid cyst)という説と，

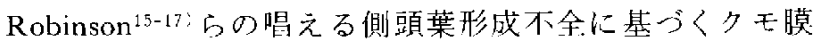

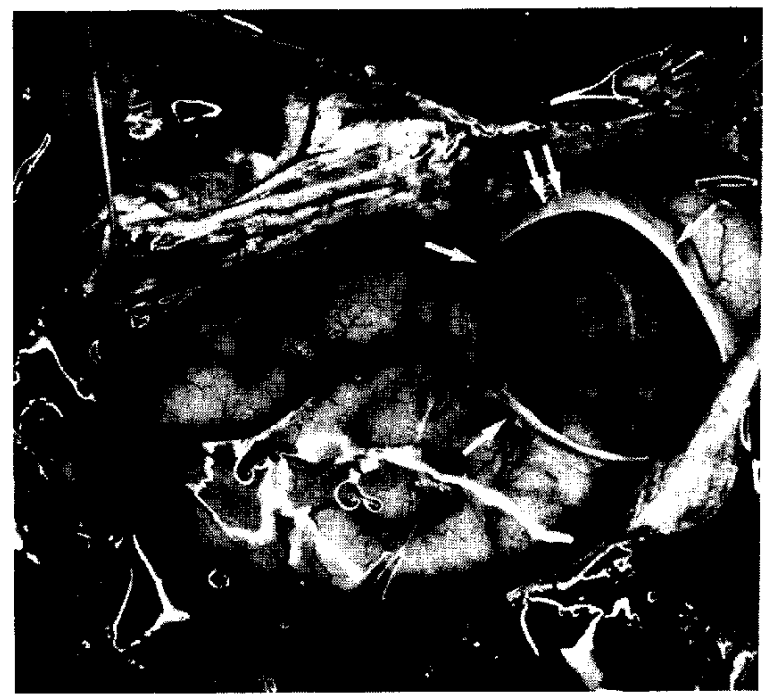

Fig. 4 Operative vicw. Arrows indicate the perimeter of the tear of the upper wall of the arachnoid cyst. Double arrow shows the portion sampled for specimen.

Fig. 3 Metrizamide CT cisternograghs performed 35 days after injury, obtained 3 hours (A), 6 hours (B), 24 hours (C), and 48 hours (D) alter intrathecal administration of metrizamide. Metrizamide is not seen in the abnormal low-density area. 
下腔の恭常による( subarachnoid cyst)という説の2つが有

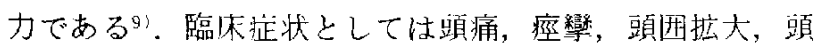
蓋内圧九進などが举げられる6,20!。しかし，Cr 無怔状例も見い出されるようになった5,8：今回の我々の

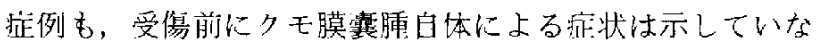
い.

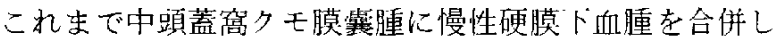
た報告はある活が，慢性硬膜下水腫を合併し，その形成 過程を詳細に追跡した報告はみあたらない，本症例では， CT スキャンにより受伤直㣪加的硬膜下腔の抬大傾向を継 続的に追跡できた。受傷徭 5 日目の metrizamide CT cisternographyでは硬膜下腔とクモ膜囊腫が完全に交通した空 間となっていることを示したが、これは受傷時の衝撃によ

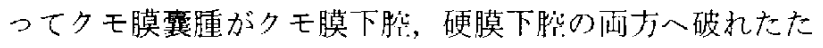
めと考えられる。のらに手術によって，クモ膜囊腫と搪大 した硬膜下腹が大きな交通を有し，全体として慢珄硬膜卜 水腫の構造を持った空閒となっていたことが確認された。 一方受傷俊35日日の metrizamide CT cisternography は, クモ膜下挖から隔離された硬膜下腔，クモ膜㟝腫を示し， 少なくともこの时点においては慢性硬膜下水腫としての構 造をとっていたと考えられる。本拝例では，东す外傷によ りクモ膜囊腫が破れ，䯣波が硬膜下腔に入り込んでいるの

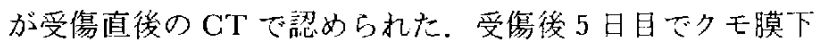
腔と硬膜下腔の完全な交通がな打詋的狄たが，35日目に は直接的な交通性はほと儿ど留方られなくなった。また CT上は，外見的に高吸双域を正すほど大量の出血はどの

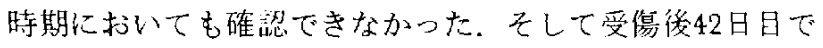
手術が行われ，慢性硬膜下水腫が確認された。

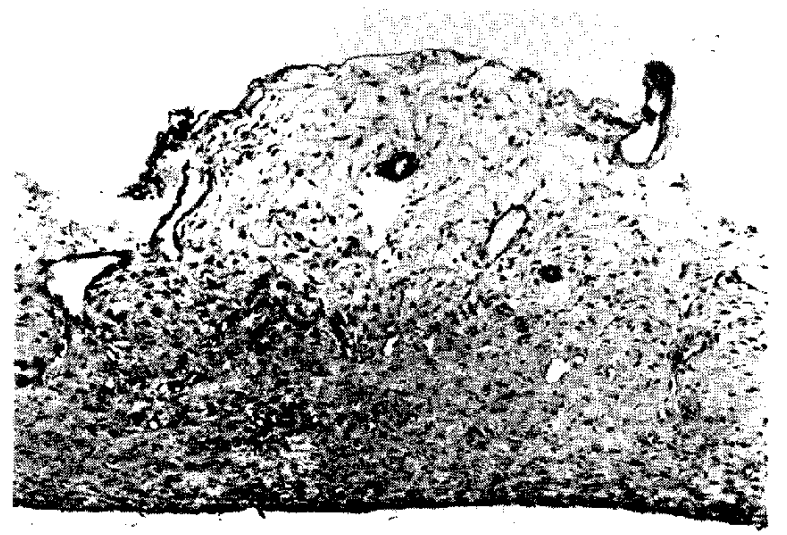

Fig. 5 Photomicrograph of the outer membrane of the hygroma. In the parietal layer, newly formed vascular sinusoidal channels are recognized. Inner layer consists of fibroblastic component with inflammatory cell invasion. HE stain, $\times 100$.

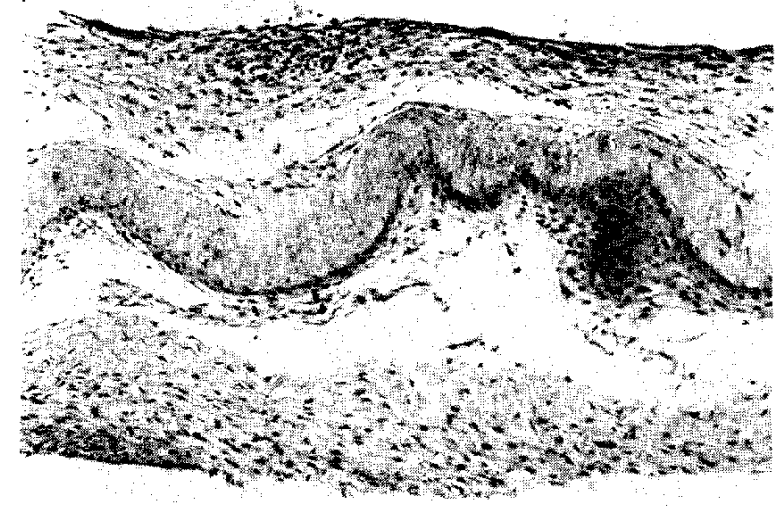

Fig. 6 Photomicrograph of the upper wall of the arachnoid cyst. Thick arachnoid membrane is seen between two fibroblastic layers with nests of inflammatory cells. $\mathrm{HE}$ stain, $\times 100$.

小竹ら ${ }^{141}$ は乳幼胃期に生ずる外傷後慢性硬膜下水腄ある いは近腫に扣いて，その被膜の組織学的構造は成人慢性硬 膜下血腫例の場合にきわめて類似すると述べている，本症 例でも成人慢性硬膜下血腫の組織学的構造 19 に酷似してい た。办腫外膜は硬膜に接する側に血管の新生がみられ sinusoidal channel 死形成し, 内腔側は線維性の層を牫し ていた(Fig. 5)。一方，クモ膜面に接与る内膜注細胞浸潤 を伴った線維性の層より形成されていた，本症例では，探 取したクモ膜囊腫上壁が両面で内腔に接した場听であった ので，肥厚したクモ膜》を線維性の層で而面より挟む状態 の組織学的所見を旺していた(Fig. 6).

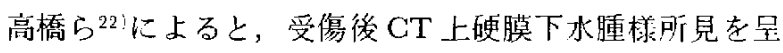
した26例中15例に慢性硬膜下血腫への移行を涩めたとい

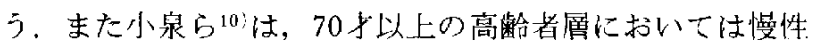
硬膜下水腫より慢性硬膜下血腫への变化圶認めたと報告し ている。これらの報告は，慢性硬膜下血腫と水腫の相違が 被膜形成後のなんらかの要素による経過の違いまたは時期 の違いによるものであることを示唆していると芯える，慢 性硬膜下血腫では内容液の凝固系・線溶系の異常九進が被 膜よりの反復する出血と関連していると考えられているか が，このような悪循環に宿る背景の换討 ${ }^{7,25}$ が今後の重要 な課題である。

真出ら ${ }^{(8)}$ は，乳睍期のある期間においてクモ膜下挖の拔 大を生理的に認めるものがあり，これが小児慢性硬膜下水 腫(拐腫)に深い関連があるのではないかと推測している. 一方成人慢性硬膜下组腫例では，脳委縮がなんらかの役割

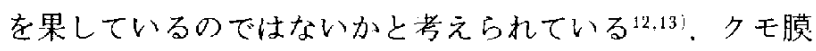
囊腫も一種のクモ膜下腔の拨大と考えられ，このような 
craniocerebral disproportion 類似の状態は，軽微な外傷や 急激な頭部の動きによってクモ膜の破綻を惹き起こしやす いと考えられる。

渡辺ら 23,24 は，実験的に髄液上血液の混合液をイ又の硬 膜下腔に置くことにより慢性硬膜ト血腫を作製できたと報 告している。しかし本拝例では，手術時内容液がキサント

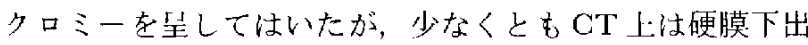
血は確認できなか一た。被膜形成に必要な混入血液星は， 彼らの報告よりは少量で可能であるのかむしれない。 Apfelbaum $5^{2)}$ は，被膜形成に本質的な問題は硬膜下腔に フィブリンが存在し硬膜と接触することであると主張して いる，兔疫電気泳動法では，正常状態の䯣液中にはフィブ リノーゲンの存在は認められない4，出血以外に硬膜下腔 の髄液中フィブリン濃度が上昇する原因として硬膜毛細血 管よりの移行が考えら札るが，能液と硬膜の接触がなんら かの引金上なっている可能性は否定できない，

我々の症例で示されたように，慢性硬膜下水腫の形成に は夕モ膜の破程による䯣液の硬膜卜腔八の侵入が，兄要であ ると考えら扎る，水腫から慢性硬膜下血腫八の移行にはな んらかの条件が必要と思われたが，今回の経騒で仕その検 討はできなかった。ただし，被膜の組織学的特微は水腫上 り血腫八の变化を起こす potentialityを水蕾被膜が持って いることを示した。

\section{$N$ まとめ}

クモ膜葓腫に伴った慢性硬膜下水腫の成立過程と手術所 見を述べた。本怔例では，クモ膜囊腫の破綻とそれによる 䯣液の硬膜下腔への貯留が水腫形成入上移行した。また， 本佂例の慢性硬膜下水腫の被膜の組織学的特微は成人慢性 硬膜下血腫のそれに酷似していた。

中頭蓋窖クモ膜囊腫は種の craniocerebral disproportionであり，一般的にこのような状態は轰微な外傷でクモ

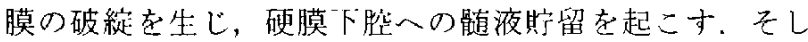
て，慢性硬膜「水腫発生にはこうしたタも膜の破䍃による 硬膜卜腔への遾液貯留が引金となると考えられ，ある条件 下では水腫は慢性硬膜下血腫八移行す万可能性を持つと思 われる。

\section{文献}

1) Anderson FM, Scgal HD, Caton WL: Use of computerized tomography scanning in supratentorial arachnoid cysts. J Neurosurg 50: 333-338, 1979

2) Apfelbaum RI, Guthkelch AN, Shulman K: Experimental production of subdural hemtomas. J Neurosurg 40: 336-346, 1974

3) Becker DP, Miller JD, Young HF, Selgorst JB, Kishore PRS, Greeivberg RP, Rosner MJ, Ward JD: Diagnosis and treatment of head injury in adults, in Youmans JR (ed): Neurological Surgery. Philadelphia, WB Saunders, 1982, $2071 \mathrm{PP}$

4) Bronnestam R, Dencker SJ, Swahn B: Fibrinogen in cerebrospinal fluid. Fibrinogen demonstrated by microimmunoelectrophoresis. Arch Neurol 4: 288-290, 1961

5) Dyck P, Gruskin P: Supratentorial arachnoid cysts in adults. A discussion of two cases from a pathophysiological and surgical perspective. Arch Neurol 34: 276-279, 1977

6）蛯名国彦，三田礼造，鈴木重晴：原発性々モ膜罴畽の成人 例。脳神外科 4: 89-94, 1976

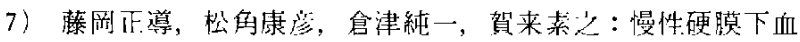
腫被膜形成に子る好酸球浸潤の意羲一特に estrogen上の関連 についてー. Neurol Med Chir (Tokyo) 23: 145-151, 1983

8) 林降士，姉川繁敬，本田英一郎，含本進賢，森件明，

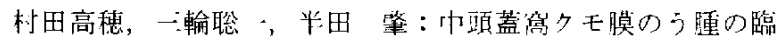
床的分析. 脳上神 31:205-214,1979

9）門脇弘孝，井出光信，高点英一，山本早绝，今永治寿，神 保 奏: 慢性硬膜下血腫老伴ったくも膜のう腫の一例。脳神 外科 11:431-436, 1983

10）小泉英仁，深町 彰，若暂哲夫，田崎 健，永関慶重，尔 内由美：成人例外傷性使膜下水腫一慢性硬膜下而腫上の関璉 性について一. Neurol Merl Chir (Tokyo) 21: 397-406, 1981

11) LaCour F, Trevor R, Carey M: Arachnoid cyst and associated subdural hematoma. Observations on conventional roentgenographic and computerized tomographic diagnosis. Arch Neural 35: 84-89, 1978

12) Miller JD, Becker DP: General principles and pathophysiology of head injury, in Youmans JR (ed): Neurological Surgery. Philadelphia, WB Saunders, 1982, $1912 \mathrm{pP}$

13）中村糺夫，小川武希，橋本卓雄，結城研司，小林茂：再 び resolving subdural hematomaについて. Neurol Med Chir (Tokyo) 21:491-500, 1981

14）小竹源也：乳幼児外傷性㹬膜下血腫（水霾）に対する外ド レナージの経験.小児の脳神 8: 67-78, 1983

15) Robinson RG: Local bulging of the skull and external hydrocephalus due to cerebral agenesis. Br.J Radiol 31: 691-700, 1958, cited in 9)

16) Robinson RG: The temporal lobe agenesis syndrome. Brain 87 : $87-106,1964$, cited in 9)

17) Rubinson RG: Congenital cysts of the brain: Arachnoid malformations. Prog Neurol Surg 4: 133-174, 1971, cited in 9)

18）真田祥一，宮下英，小川勉，槁本卓雄，関野宏明，中 村紀夫：拡大した乳兄クモ膜下腔と䯠液唄溜 一 Subdural effusion との関連珄一. Neurol Med Chir (Tokyo) 21: 155-162, 1981

19) Sato S, Suzuki J: Ultrastructural observations of the capsule of chronic subdural hematoma in various clinical stages. $J$ Neurosurg 43: $569-578,1975$

20) Smith RA, Smith WA: Arachnoid cysts of the middle cranial fossa. Surg Neurol 5: 246-252, 1976

21) Starkman SP, Brown TC: Cerebral arachnoid cysts. $J$ Neuropathol Exp Neurol 17: 484-500, 1958, cited in 9)

22）高橋羕男, 佐藤宏之, 井上慶俊, 武田 聡, 大川原幑二： 
慢性硬膜下血腫のCT 的検討（第 1 報）一之の発生予測一， Neural Med Chir (Tokyo) 21: 485-490, 1981

23）渡讯 学, 石井昌三: 慢性硬膜下血腫の成因. 脳神外科 2 275-281, 1974

24) Watanabe S, Shimada H, Ishii S: Production of clinical form of chronic subdural hematoma in experimental animals. I Neurasurg 37: $552-561,1972$
25）山本信二郎：慢性硬膜下血腫. Neurol Med Chir（Tokyo）19: 401-409, 1979

[別刷請求先：干213 神奈川県川崎市宫街区营生 2,095 , 聖マリ アン十医科大学第 2 外科学教公脸神経外科診㞠科, 楠野幸次了 